\title{
OPTIMIZATION OF THE ANP AND SET COVERING METHOD FOR THE ALLOCATION OF TANKER IN THE EAST SEA REGION OF INDONESIA
}

\author{
Ahmadi, Arica Dwi Susanto, Arys Susanto, Okol S Suharyo \\ Indonesian Naval Technology College, STTAL \\ Bumimoro-Morokrembangan, Surabaya 60187, Indonesia
}

\begin{abstract}
As an archipelago which has a wider sea area than land, Indonesia, in this case the oil company, must be able to serve and accommodate oil throughout the Indonesian sea, especially the eastern region. The lack of tanker cause the run out of fuel oil in remote areas, so there needs to be a sector division included in oil companies. The method used by researchers was the Analytic Network Process (ANP) approach and the set covering problem method. By determining the right dock location for the Tanker, the dock would be able to cover the entire existing sector, and through the determination of the proper tanker assignment plan, the entire territory of Eastern Indonesia would be able to be covered by the presence of the Tanker. The results of the study show that the candidate starting point assignment was produced by 4 (four) ports as the starting point for the assignment of tankers. These ports consist of Ambon in charge of covering sectors 4, 5, 6 and 7, Makasar port was in charge of sector 1 and to cover sector 3 while Tegal port is in charge of covering the patrol sector 2 .
\end{abstract}

Keywords: ANP, Set Covering Problem, Optimization, Tanker

\section{INTRODUCTION.}

As an archipelago which has a wider sea area than land, Indonesia, in this case the oil company, must be able to serve and accommodate oil throughout the Indonesian sea, especially the eastern region. As a supporting component of national defense at sea, the Government strongly supports oil companies that can facilitate the needs of fishing vessels or government-owned vessels. Thus, the ships don't need to worry about running out of oil in the middle of the sea.

This paper used some kinds of literature to support the research, for example paper titled Application of Analytic Network Process (ANP) in Business Environment: A Comprehensive Literature Review (A. Jayant, 2015). Comparative Analysis Results of Towing Tank and Numerical Calculations With Harvald Guldammer Method (I Nengah Putra, 2017). Applying the ANP Model for Selecting the Optimal Full-service Advertising Agency (Pi-Fang Hsu, 2011). Using Analytical Network Process (Anp)
Method To Prioritize Strategies Resulted From Swot Matrix Case Study: Neda Samak Ashena Company (Mohammadreza Shojaei, 2013). Type of Ship Trim Analysis on Fuel Consumption with a Certain Load and Draft (I Nengah Putra, 2017) Analytical Network Process (ANP) to Recommend an Ice Cream to a Diabetic Patient (Suhas M. Gaikwad, 2015). Relaxation Heuristics For The Set Covering Problem (Shunji Umetani, 2007). Technology Selection for Product Innovation Using Analytic Network Process (ANP)-A Case Study (Thangamani, 2012). Analysis of The Propulsion System Towards The Speed Reduction of Vessels Type PC-43 (Arica Dwi Susanto, 2017). Energy-Aware Set-Covering Approaches for Approximate Data Collection in Wireless Sensor Networks (Chih-Chieh Hung, 2012). Fundamentals of The Analytic Network

Process-Dependence and Feedback in DecisionMaking With a Single Network (Saaty, 2004). Multidimensional Balanced Efficiency Decision Model (Fabio De Felice, 2015). Solution of 
Problem of Set Covering by Means of Genetic Algorithm (Ananiashvili, 2015). Comparative Study of AHP and ANP on Multi-Automotive Suppliers with Multi-Criteria (Amir Azizi, 2014). Consistency Test in ANP Method with Group Judgment Under Intuitionistic Fuzzy Environment (Son, 2014). Improved Association Rules Mining based on Analytic Network Process in Clinical Decision Making (Khademolqorani, 2016). Food Sustainable Model Development: An ANP Approach to Prioritize Sustainable Factors in the Romanian Natural Soft Drinks Industry Context (Răzvan Cătalin Dobrea, 2015). The Optimization Of Multipurpose Building Development On Project Scheduling Using Precedence Diagram Method (PDM) (Arica Dwi Susanto, 2018). An Efficient Mean Field Approach to The Set Covering Problem (Mattias Ohlsson, 2001). A Unified Model and Analysis For AHP and ANP (Takahashi, 2001). The DEA-FUZZY ANP Department Ranking Model Applied in Iran Amirkabir University (Babak Daneshvar Rouyendegh, 2010). Quality Function Deployment (QFD) and Analytic Network Process (ANP): an application to analyze a cohousing intervention (Lami, 2012). The Research on Energy-saving Technology of the Set Covering Base Station in Cellular Networks (Tian, 2014). The Set Covering Machine (Shawe-Taylor, 2002). Absolute o (logm) error in approximating random set covering: an average case analysis (Orestis A. Telelis, 2005).

The calculations used in this study was the Analytic Network Process (ANP) approach and the set covering problem method. By determining the right dock location for the Tanker, the dock would be able to cover the entire existing sector, and through the determination of the proper tanker assignment plan, the entire territory of Eastern Indonesia would be able to be covered by the presence of the Tanker.

\section{MATERIALS/METHODOLOGY.}

\subsection{Multiple Criteria Decision Making (MCDM)}

In this life, humans are always faced with various problems. One problem that is certainly would be experienced by humans is how to make an appropriate decision on various existing choices (alternatives) and criteria (attributes). Therefore, because of human intelligence and the desire to solve these problems, various methods and solutions were made. One of the most often used methods is the Multiple Criteria Decision Making (MCDM).

Problems with many criteria may be defined as a situation where a criterion is a consideration for choosing an alternative that is used:

1. To determine the best alternative or a set of the best alternatives (choice problems).

2. To rank alternatives from the best to the worst (ranking issues).

3. To divide alternative sets into alternative subsets based on several rules (sorting problems).

In real life problem, we often meet with several categories to select the best alternative design (choice problem) and prioritize the best alternative (ranking problem). Multiple Criteria Decision Making (MCDM) is a decision-making method consisting of theories, processes, and analytical methods for decision making involving uncertainty, dynamics, and multicriteria aspects of a decision. In MCDM, the use of conventional optimization methods is generally limited to only one selection criterion, where the selection taken is the choice that best meets the objective function. However, the problems, especially those practical problems, are not that simple. There 
are times when subjective considerations must be included in the decision making process. For this reason, the MCDM method provides an alternative to utilizing objective and subjective considerations as the basis for decision making. There are two groups in MCDM, which are decision-making groups based on selected attributes or often known as Multiple Attribute Decision Making (MADM) and groups that are based on the synthesis of selected attributes or often called Multiple Objective Decision Making (MODM).

Multiple Objective Decision Making (MODM) uses an optimization approach, thus the mathematical model has to be found first in order to solve the problem. Then, it is maximized or minimized according to the mathematical model that has been obtained. Meanwhile, the Multiple Attribute Decision Making (MADM) uses a selection approach by first setting quantitative attributes and qualitative attributes of the components to be selected.

Multiple Criteria Decision Making (MCDM) is the terminology used in solving problems where there are two or more criteria that are not commensurate and contradictory. So that the presence of the MCDM approach is expected to get the best alternative (Saaty, 2004)

\subsection{Analytic Network Process (ANP)}

Analytic Network Process (ANP) is a method that produces a framework to overcome decision-making problems without involving assumptions related to independence between higher level elements with weak and independent elements in one level.

Like the AHP, ANP involves hierarchical relationships. Hierarchical control, however, does not require a standard structure such as the AHP so that it can handle complex relationships between decision levels with attributes. This ANP models the system with feedback and system where one level may dominate or be dominated, both directly and indirectly by other levels. In ANP, a pairwise comparison method is used as in the AHP. This pairwise comparison process uses numbers/scales that reflect the level of importance/preference of a decision element with other decision elements in the same hierarchy level. This helps decision makers to compare each element of the decision, because in each paired comparison, they only concentrate on two of them.

Table 1. Pairwise Comparison Scale

\begin{tabular}{|c|c|}
\hline $\begin{array}{c}\text { Importance } \\
\text { Level }\end{array}$ & Definition \\
\hline 1 & $\begin{array}{l}\text { Both elements are equally } \\
\text { important }\end{array}$ \\
\hline 3 & $\begin{array}{c}\text { One element is slightly more } \\
\text { important than the other } \\
\text { elements. }\end{array}$ \\
\hline 5 & $\begin{array}{l}\text { One element is actually more } \\
\text { important than the other } \\
\text { elements. }\end{array}$ \\
\hline 7 & $\begin{array}{l}\text { One element is clearly more } \\
\text { important than the other } \\
\text { elements. }\end{array}$ \\
\hline 9 & $\begin{array}{c}\text { One element is absolutely } \\
\text { more } \\
\text { important than other elements. }\end{array}$ \\
\hline $2,4,6,8$ & $\begin{array}{l}\text { Middle values between } 2 \\
\text { adjoining assessments. }\end{array}$ \\
\hline
\end{tabular}

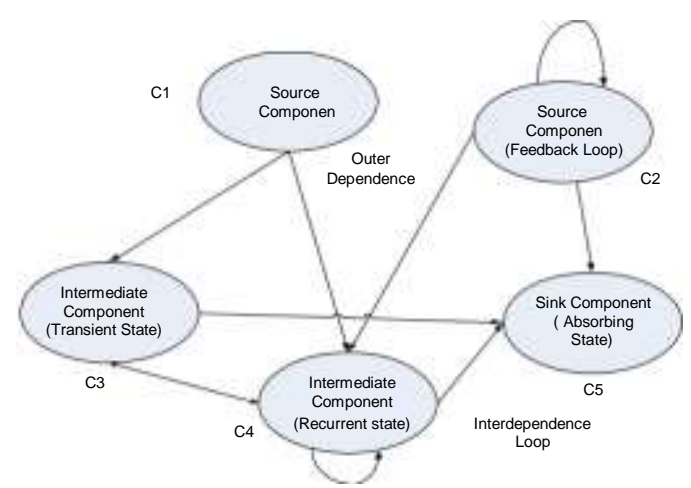

Fig. 1 Feedback network Structure 


\section{Steps for Resolving ANP:}

1. Step 1: Constructing and structuring the problem.

2. Step 2: Pairwise comparison matrix that shows the relevance

3. Step 3: Calculation of the consistency ratio

$\mathrm{Cl}=(\lambda \max -\mathrm{N}) /(\mathrm{N}-1) 2.1$

4. Step 4: Supermatrix formation and analysis

5. Step 5: Choose the best alternative.

\section{Set Covering Problem}

The covering set is one part of the problem of location-allocation. The purpose and location-allocation model is to determine the location of facilities that can minimize the cost of assigning facilities to customers by limiting that each facility is assigned to a set number of customers. Service to customers from facilities to be placed depends on the distance between the customer and the facilities assigned to the customer. The problem of set covering is to place the minimum number of facilities needed to cover all node demand.

Formulation of location minimalized problem solving was defined as follows:

$I=$ set from node demand indexed by $i$. $\mathrm{j}=$ set of Port location candidate indexed by $\mathrm{j}$.

$d_{(i, j)}=$ length between candidate $\mathrm{i}$ and node demand $\mathrm{j}$.

$$
\begin{aligned}
& >\quad \mathrm{D}_{\mathrm{c}}=\text { range. } \\
& >\quad \mathrm{N}_{\mathrm{j}}=\left\{\mathrm{j} \backslash \mathrm{d}(\mathrm{i}, \mathrm{j}) \leq \mathrm{D}_{\mathrm{c}}\right\}
\end{aligned}
$$

\section{Result}

In this section, data collection was performed to those which were relevant and related to existing problems. The data obtained was used as input for data processing to find the optimal solution to the existing problems. Data collection and processing was performed to $r$ determine the weight of the dock. Data collection was subsequently performed for the completion of the modeling Set Covering Problem. Processing data with Set Covering Problem was performed in two stages, the first stage was processing with the aim of maximizing the weight and coverage of the dock. The second stage was processing with a purpose in which modeling was made using the results of processing in the first stage or was the result of processing the first goal.

Port names and naming codes (for assisting the ANP calculations) is shown in table 2 below:

Table 2. Name and coding in ANP Calculation

\begin{tabular}{|c|c|c|c|c|c|}
\hline No. & Name & Code & No. & Name & Code \\
\hline 1 & DOCK & $\mathrm{P}$ & 23 & KOTABARU & $\mathrm{A} 13$ \\
\hline 2 & OPERATIONAL & $\mathrm{D}$ & 24 & KUPANG & $\mathrm{A} 14$ \\
\hline 3 & $\begin{array}{c}\text { ENVIRONTMENT } \\
\text { CONDITION }\end{array}$ & $\mathrm{K}$ & 25 & MAKASAR & $\mathrm{A} 15$ \\
\hline 4 & SUPPLY & $\mathrm{D} 1$ & 26 & MANADO & $\mathrm{A} 16$ \\
\hline 5 & REPAIRMENT & $\mathrm{D} 2$ & 27 & MATARAM & $\mathrm{A} 17$ \\
\hline 6 & PORT & $\mathrm{D} 3$ & 28 & MAUMERE & $\mathrm{A} 18$ \\
\hline 7 & PERSONNEL & $\mathrm{D} 4$ & 29 & MERAUKE & $\mathrm{A} 19$ \\
\hline 8 & $\begin{array}{c}\text { CLIMATE AND } \\
\text { WHEATHER }\end{array}$ & $\mathrm{K} 1$ & 30 & NUNUKAN & $\mathrm{A} 20$ \\
\hline 9 & $\begin{array}{c}\text { GEOGRAPHIC } \\
\text { CONDITION }\end{array}$ & $\mathrm{K} 2$ & 31 & P.ROTE & $\mathrm{A} 21$ \\
\hline 10 & SUMDA CONDITION & $\mathrm{K} 3$ & 32 & PALU & $\mathrm{A} 22$ \\
\hline
\end{tabular}




\begin{tabular}{|c|c|c|c|c|c|}
\hline No. & Name & Code & No. & Name & Code \\
\hline 11 & AMBON & A1 & 33 & SANGATA & A23 \\
\hline 12 & ARU & A2 & 34 & SEMARANG & A24 \\
\hline 13 & BALIKPAPAN & A3 & 35 & SORONG & A25 \\
\hline 14 & BANJARMASIN & A4 & 36 & SURABAYA & A26 \\
\hline 15 & BANYUWANGI & A5 & 37 & TAHUNA & A27 \\
\hline 16 & BATUPORON & A6 & 38 & TARAKAN & A28 \\
\hline 17 & BIAK & A7 & 39 & TEGAL & A29 \\
\hline 18 & CILACAP & A8 & 40 & TERNATE & A30 \\
\hline 19 & DENPASAR & A9 & 41 & TIMIKA & A31 \\
\hline 20 & GORONTALO & A10 & 42 & TOLI-TOLI & A32 \\
\hline 21 & JAYAPURA & A11 & 43 & TUAL & A33 \\
\hline 22 & KENDARI & A12 & & & \\
\hline
\end{tabular}

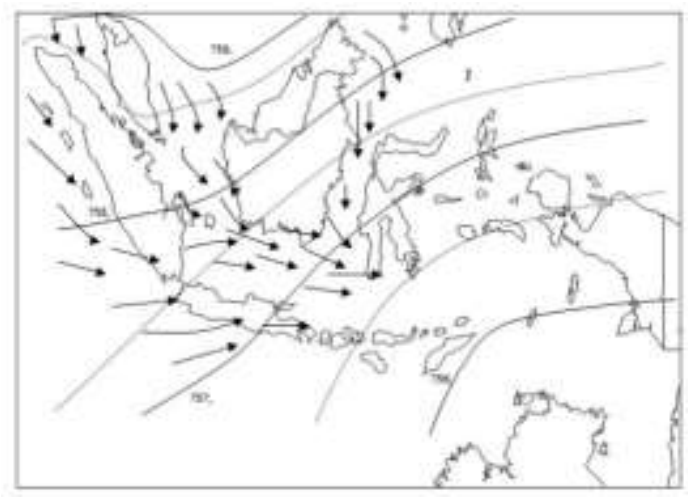

Fig. 2 Isobar Lines and Wind Directions for January-February in the Indonesian Archipelago

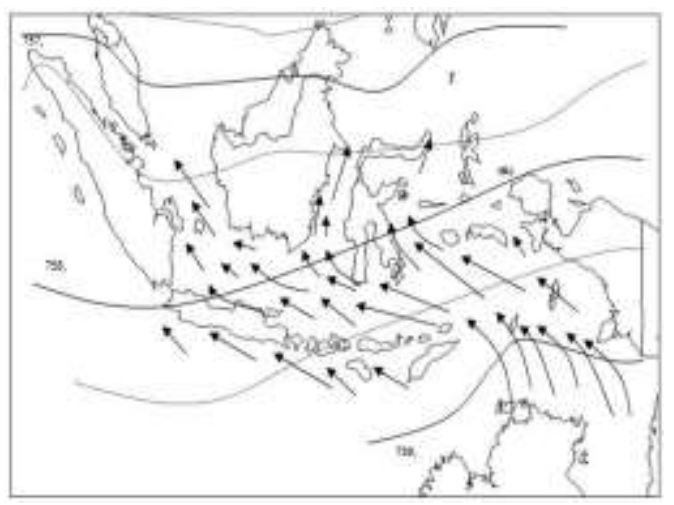

Fig. 3 Isobar Lines and Wind Directions for JulyAugust-September in the Indonesian Archipelago

\section{Pairwise Comparison}

The next stage after data was obtained, is data processing activities. With regard to the method used in this study, the ANP method and the data processing is used and performed through the help of Super
Decisions Software. The processed data was questionnaire data which was the respondent's perception regarding the prioritization of the tanker dock.

Table 3. Pairwise Comparison between Criteria

\begin{tabular}{|c|c|c|}
\hline & $B$ & $K$ \\
\hline$B$ & 1,00 & 1,00 \\
\hline$K$ & & 1,00 \\
\hline
\end{tabular}

Table 4. Pairwaise Comparison Inter-subcriteria in Operational Supporting Criteria

\begin{tabular}{|c|c|c|c|c|}
\hline & D1 & D2 & D3 & D4 \\
\hline D1 & 1,00 & 2,94 & 2,29 & 5,12 \\
\hline D2 & & 1,00 & 0,32 & 3,09 \\
\hline D3 & & & 1,00 & 3,03 \\
\hline D4 & & & & 1,00 \\
\hline
\end{tabular}

Table 5. Pairwaise Comparison Inter-subcriteria in Environment Condition

\begin{tabular}{|c|c|c|c|}
\hline & K1 & K2 & K3 \\
\hline K1 & 1,00 & 1,00 & 3,09 \\
\hline K2 & & 1,00 & 3,03 \\
\hline K3 & & & 1,00 \\
\hline
\end{tabular}

Table 6. Pairwise Comparison affecting Source Condition Geographically on Subcriteria Weather Climate and Resource Conditions.

\begin{tabular}{c|c|c}
\hline & K1 & K3 \\
\hline K1 & 1,00 & 2,94 \\
\hline K3 & & 1,00
\end{tabular}




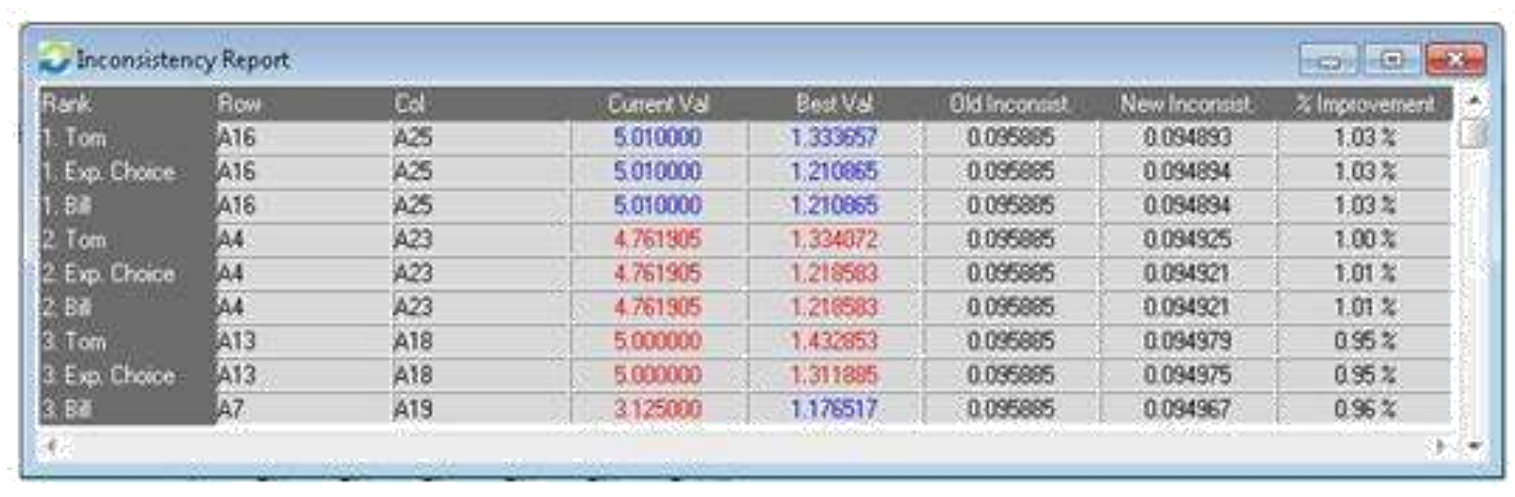

Fig. 4 Total Inconsistency Report in Supply Facility Subcriteria

Table 7. Alternative Priority

\begin{tabular}{|c|c|c|c|c|c|}
\hline NO. & Name & Ideals & Normal's & Raw & Dock \\
\hline 1 & A26 & 1.000 .000 & 0.129184 & 0.035484 & SURABAYA \\
\hline 2 & A15 & 0.566836 & 0.073226 & 0.020113 & MAKASAR \\
\hline 3 & A24 & 0.557147 & 0.071975 & 0.019770 & SEMARANG \\
\hline 4 & $\mathrm{~A} 1$ & 0.519812 & 0.067152 & 0.018445 & AMBON \\
\hline 5 & A16 & 0.516969 & 0.066784 & 0.018344 & MANADO \\
\hline 6 & A3 & 0.432721 & 0.055901 & 0.015355 & BALIKPAPAN \\
\hline 7 & A17 & 0.369779 & 0.047770 & 0.013121 & MATARAM \\
\hline 8 & A25 & 0.324549 & 0.041927 & 0.011516 & SORONG \\
\hline 9 & A5 & 0.262854 & 0.033957 & 0.009327 & BANYUWANGI \\
\hline 10 & A14 & 0.247952 & 0.032031 & 0.008798 & KUPANG \\
\hline 11 & A23 & 0.222884 & 0.028793 & 0.007909 & TEGAL \\
\hline 12 & A29 & 0.218793 & 0.028265 & 0.007764 & CILACAP \\
\hline 13 & A8 & 0.200775 & 0.025937 & 0.007124 & SANGATA \\
\hline 14 & A33 & 0.198949 & 0.025701 & 0.007059 & DENPASAR \\
\hline 15 & A9 & 0.197727 & 0.025543 & 0.007016 & BANJARMASIN \\
\hline 16 & A4 & 0.188271 & 0.024322 & 0.006681 & TUAL \\
\hline 17 & $\mathrm{~A} 11$ & 0.179952 & 0.023247 & 0.006385 & JAYAPURA \\
\hline 18 & A18 & 0.171118 & 0.022106 & 0.006072 & PALU \\
\hline 19 & $\mathrm{~A} 22$ & 0.165350 & 0.021361 & 0.005867 & MAUMERE \\
\hline 20 & A28 & 0.155704 & 0.020114 & 0.005525 & TARAKAN \\
\hline 21 & $\mathrm{~A} 12$ & 0.141321 & 0.018256 & 0.005015 & KENDARI \\
\hline 22 & A20 & 0.100487 & 0.012981 & 0.003566 & NUNUKAN \\
\hline 23 & A27 & 0.090046 & 0.011632 & 0.003195 & BATUPORON \\
\hline 24 & A10 & 0.089717 & 0.011590 & 0.003183 & GORONTALO \\
\hline 25 & A6 & 0.089504 & 0.011563 & 0.003176 & KOTABARU \\
\hline 26 & A13 & 0.085271 & 0.011016 & 0.003026 & TAHUNA \\
\hline 27 & A30 & 0.074759 & 0.009658 & 0.002653 & BIAK \\
\hline 28 & A7 & 0.074752 & 0.009657 & 0.002652 & TERNATE \\
\hline 29 & A31 & 0.063919 & 0.008257 & 0.002268 & TIMIKA \\
\hline 30 & A19 & 0.061914 & 0.007998 & 0.002197 & MERAUKE \\
\hline 31 & A32 & 0.060671 & 0.007838 & 0.002153 & TOLI-TOLI \\
\hline 32 & $\mathrm{~A} 2$ & 0.056411 & 0.007287 & 0.002002 & $\mathrm{ARU}$ \\
\hline 33 & A21 & 0.053973 & 0.006972 & 0.001915 & P.ROTE \\
\hline
\end{tabular}

\section{Alternative Sensitivity Analysis}

Sensitivity analysis was performed by using Super Decision software by changing the weight values on alternatives. So it would be known whether by changing the value of the weight value in the alternative, it would affect the results of the initial ranking or not. When there is a change in ranking, the change is called the critical point of an alternative. 


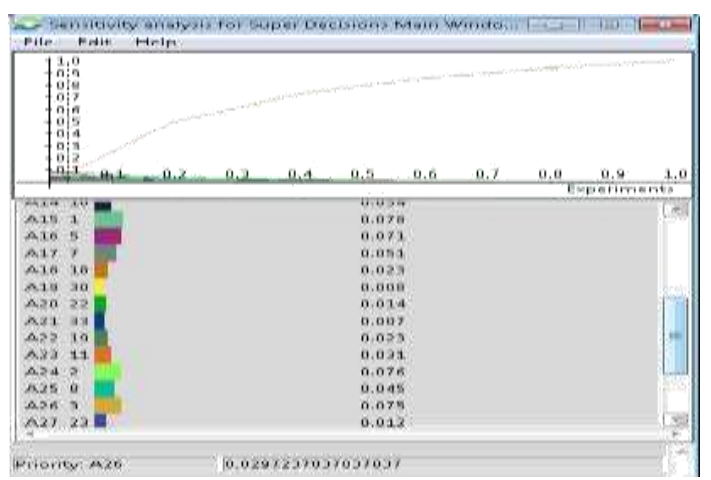

Fig. 5 Sensitivity Diagram

\section{Set Covering Method}

Calculate the distance and extent of coverage of tankers during sailing.

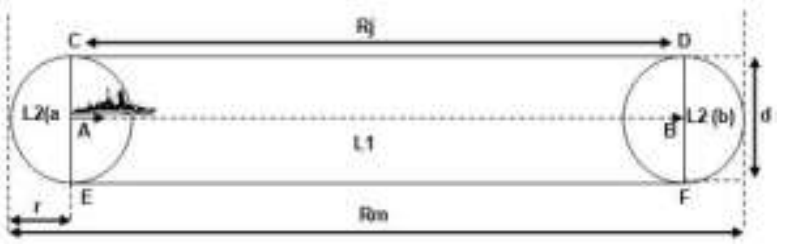

Fig. 6 The range area of Tanker Coverage

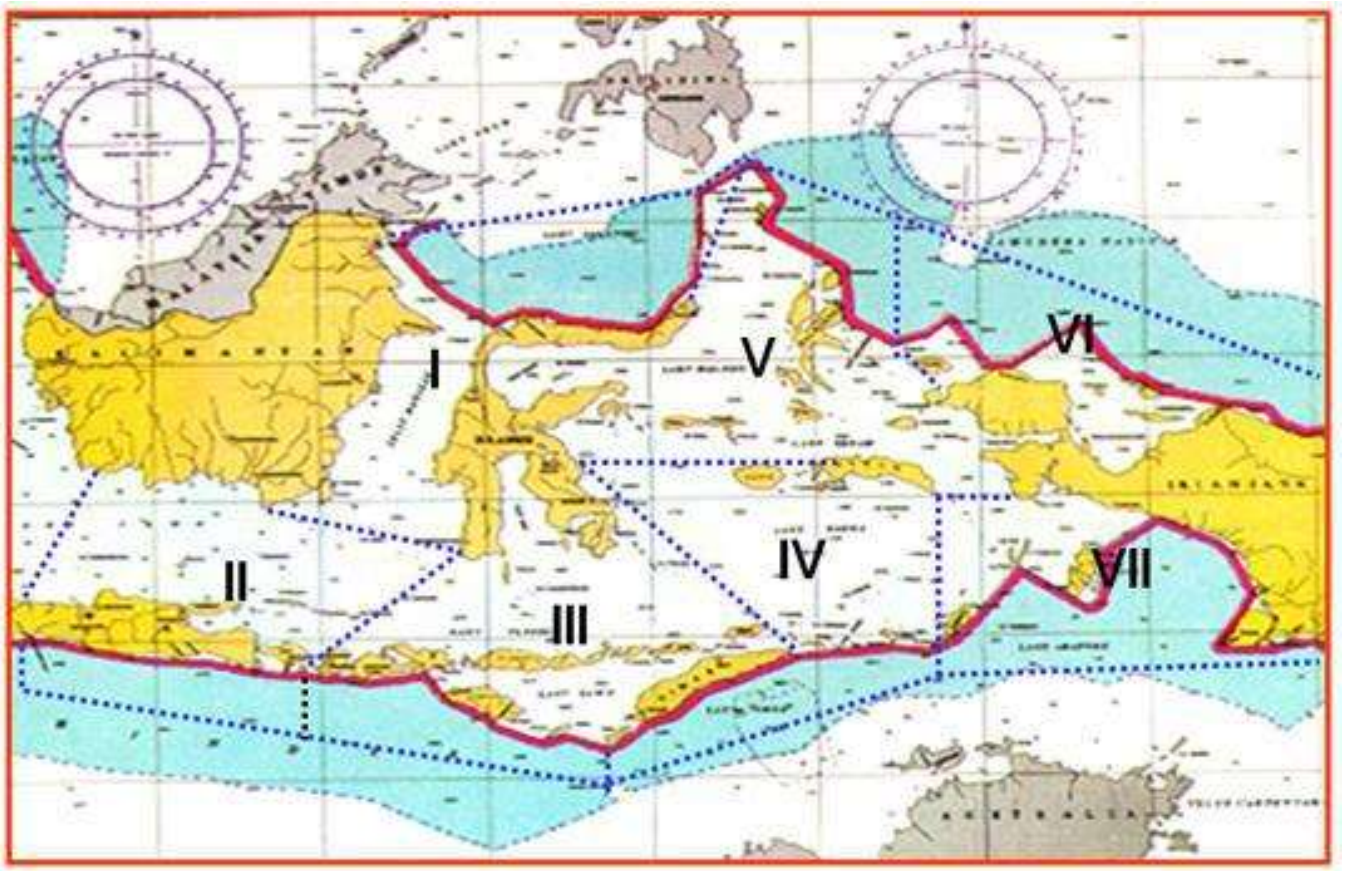

Fig. 7 Patrol Sector Map of Eastern Indonesia Region

Table 8. Zero-One Results The Second Purpose Function of One Tanker Unit

\begin{tabular}{|l|c|c|c|c|c|c|c|}
\hline \multirow{2}{*}{\multicolumn{1}{c|}{ DOCK }} & \multicolumn{7}{|c|}{ SECTOR } \\
\cline { 2 - 8 } & $\mathbf{1}$ & $\mathbf{2}$ & $\mathbf{3}$ & $\mathbf{4}$ & $\mathbf{5}$ & $\mathbf{6}$ & $\mathbf{7}$ \\
\hline AMBON & 1 & 1 & 1 & 1 & 1 & 1 & 1 \\
\hline BALIKPAPAN & 1 & 1 & 1 & 1 & 1 & 1 & 1 \\
\hline BANYUWANGI & 1 & 1 & 1 & 1 & 1 & 1 & 1 \\
\hline MAKASAR & 1 & 1 & 1 & 1 & 1 & 1 & 1 \\
\hline MATARAM & 1 & 1 & 1 & 1 & 1 & 1 & 1 \\
\hline SEMARANG & 1 & 1 & 1 & 1 & 1 & 1 & 1 \\
\hline TEGAL & 1 & 1 & 1 & 1 & 1 & 1 & 1 \\
\hline
\end{tabular}

Table 9. Zero-One Results The Second Purpose Function of Four Tanker Units

\begin{tabular}{|l|c|c|c|c|c|c|c|}
\hline \multirow{2}{*}{\multicolumn{1}{c|}{ Dock }} & \multicolumn{7}{|c|}{ SECTOR } \\
\cline { 2 - 8 } & $\mathbf{1}$ & $\mathbf{2}$ & $\mathbf{3}$ & $\mathbf{4}$ & $\mathbf{5}$ & $\mathbf{6}$ & $\mathbf{7}$ \\
\hline AMBON & 0 & 0 & 0 & 1 & 1 & 1 & 1 \\
\hline MAKASAR & 1 & 0 & 0 & 0 & 0 & 0 & 0 \\
\hline MATARAM & 0 & 0 & 1 & 0 & 0 & 0 & 0 \\
\hline TEGAL & 0 & 1 & 0 & 0 & 0 & 0 & 0 \\
\hline
\end{tabular}




\section{RESULT AND DISCUSSION.}

Based on the results obtained from data collection and processing, the analysis and interpretation of the results, the output of the Super Decisions program and optimization of the LINGO program show that the results of weighting of the Port candidates, the location of the selected Port and the assignment plan for Tanker Ships are as follows:
3.1. The weighting of Port Candidate with ANP

The weighting results for 33 (thirty three) candidates for the Port that will be used as Ports for Tanker show the alternative priority of the Port as follows:

Table 10. Port Alternative Priority

(Source: Processed Data with Software Super Decisions)

\begin{tabular}{|c|c|c|c|c|c|}
\hline NO. & Name & Ideals & Normal's & Raw & Port \\
\hline 1 & A26 & 1.000 .000 & 0.129184 & 0.035484 & SURABAYA \\
\hline 2 & A15 & 0.566836 & 0.073226 & 0.020113 & MAKASAR \\
\hline 3 & A24 & 0.557147 & 0.071975 & 0.019770 & SEMARANG \\
\hline 4 & $\overline{\mathrm{A} 1}$ & 0.519812 & 0.067152 & 0.018445 & AMBON \\
\hline 5 & A16 & 0.516969 & 0.066784 & 0.018344 & MANADO \\
\hline 6 & A3 & 0.432721 & 0.055901 & 0.015355 & BALIKPAPAN \\
\hline 7 & A17 & 0.369779 & 0.047770 & 0.013121 & MATARAM \\
\hline 8 & A25 & 0.324549 & 0.041927 & 0.011516 & SORONG \\
\hline 9 & A5 & 0.262854 & 0.033957 & 0.009327 & BANYUWANGI \\
\hline 10 & $\overline{\mathrm{A} 14}$ & 0.247952 & 0.032031 & 0.008798 & KUPANG \\
\hline 11 & A23 & 0.222884 & 0.028793 & 0.007909 & TEGAL \\
\hline 12 & A29 & 0.218793 & 0.028265 & 0.007764 & CILACAP \\
\hline 13 & $\bar{A} 8$ & 0.200775 & 0.025937 & 0.007124 & SANGATA \\
\hline 14 & A33 & 0.198949 & 0.025701 & 0.007059 & DENPASAR \\
\hline 15 & A9 & 0.197727 & 0.025543 & 0.007016 & BANJARMASIN \\
\hline 16 & $\bar{A} 4$ & 0.188271 & 0.024322 & 0.006681 & $\overline{T U A L}$ \\
\hline 17 & A11 & 0.179952 & 0.023247 & 0.006385 & JAYAPURA \\
\hline 18 & A18 & 0.171118 & 0.022106 & 0.006072 & PALU \\
\hline 19 & A22 & 0.165350 & 0.021361 & 0.005867 & MAUMERE \\
\hline 20 & A28 & 0.155704 & 0.020114 & 0.005525 & TARAKAN \\
\hline 21 & $\mathrm{~A} 12$ & 0.141321 & 0.018256 & 0.005015 & $\overline{\text { KENDARI }}$ \\
\hline 22 & A20 & 0.100487 & 0.012981 & 0.003566 & NUNUKAN \\
\hline 23 & A27 & 0.090046 & 0.011632 & 0.003195 & BATUPORON \\
\hline 24 & $\mathrm{~A} 10$ & 0.089717 & 0.011590 & 0.003183 & GORONTALO \\
\hline 25 & A6 & 0.089504 & 0.011563 & 0.003176 & KOTABARU \\
\hline 26 & $\mathrm{~A} 13$ & 0.085271 & 0.011016 & 0.003026 & TAHUNA \\
\hline 27 & A30 & 0.074759 & 0.009658 & 0.002653 & BIAK \\
\hline 28 & A7 & 0.074752 & 0.009657 & 0.002652 & TERNATE \\
\hline 29 & A31 & 0.063919 & 0.008257 & 0.002268 & TIMIKA \\
\hline 30 & A19 & 0.061914 & 0.007998 & 0.002197 & MERAUKE \\
\hline 31 & A32 & 0.060671 & 0.007838 & 0.002153 & TOLI-TOLI \\
\hline 32 & A2 & 0.056411 & 0.007287 & 0.002002 & ARU \\
\hline 33 & A21 & 0.053973 & 0.006972 & 0.001915 & P.ROTE \\
\hline
\end{tabular}

the distance of coverage of Tanker Vessels.

\subsection{Determination of Ports with ANP and}

\section{Set Covering}

Determination of Ports was performed

by combining the Port weighting results and
The result from the optimization of output from 
the LINGO program show that from 33 (thirty three) Port candidates, 7 (seven) piers were selected as ports for tanker ships consisting of:

Table 11. Selected Port

\begin{tabular}{|c|c|}
\hline No. & Port \\
\hline 1 & AMBON \\
\hline 2 & BALIKPAPAN \\
\hline 3 & BANYUWANGI \\
\hline 4 & MAKASAR \\
\hline 5 & MATARAM \\
\hline 6 & SEMARANG \\
\hline 7 & TEGAL \\
\hline
\end{tabular}

Table 12. Not Selected Port

\begin{tabular}{|c|c|c|c|c|c|}
\hline No. & Port & No. & Port & & \\
\hline 1 & $\overline{A R U}$ & 14 & MERAUKE & & \\
\hline 2 & BANJARMASIN & 15 & NUNUKAN & & \\
\hline 3 & BATUPORON & 16 & P.ROTE & & \\
\hline 4 & BIAK & 17 & PALU & & \\
\hline 5 & CILACAP & 18 & SANGATA & & \\
\hline 6 & DENPASAR & 19 & SORONG & & \\
\hline 7 & GORONTALO & 20 & SURABAYA & & \\
\hline 8 & JAYAPURA & 21 & TAHUNA & & \\
\hline 9 & KENDARI & 22 & TARAKAN & & \\
\hline 10 & KOTABARU & 23 & TERNATE & & \\
\hline 11 & KUPANG & 24 & TIMIKA & & \\
\hline 12 & MANADO & 25 & TOLI-TOLI & & \\
\hline 13 & MAUMERE & 26 & TUAL & & \\
\hline \multirow{3}{*}{\multicolumn{2}{|c|}{ ssignment Planning }} & & $B$ & MAKASAR & 1 \\
\hline & & & $\mathrm{C}$ & MATARAM & 3 \\
\hline & & & $\mathrm{D}$ & TEGAL & 2 \\
\hline
\end{tabular}

\section{with Set Covering}

Determination of Assignment Planning

Based on the determination of Tanker assignment planning that used coverage area limits, it was found that the result was not optimal, this means that when tanker faced with the presence of an extensive division of the existing patrol sector, it would not be able to carry out individual patrols.

The LINGO program output will be optimal when the coverage limitation function uses an area of 4 (four) tankers. Changes to the limit function will be obtained by optimizing Tanker Ship assignments as follows:

Table 13. Selected Port in Assignment Plan

\begin{tabular}{|c|c|c|c|}
\hline No. & Code & Port & Sector \\
\hline 1 & A & AMBON & $4,5,6,7$ \\
\hline
\end{tabular}

Table 14. Not Selected Port in Assignment Plan

\begin{tabular}{c|l}
\hline No. & \multicolumn{1}{|c}{ Port } \\
\hline 1 & BANYUWANGI \\
\hline 2 & SEMARANG
\end{tabular}

\section{CONCLUSION.}

Based on the calculation and analysis of ANP data and Set Covering along with the output optimization results from the LINGO program, it shows that from 33 (thirty three), the researchers concluded that the selected ports were 7 ports (Ambon, Balikpapan, Banyuwangi, Makassar, Mataram, Semarang, Tegal) while there were 13 unselected ports (Aru, Banjarmasin, Batuporon, Biak, Cilacap, Denpasar, Gorontalo, Jayapura, 
Kendari, Kotabaru, Kupang, Manado, Maumere, Merauke, Nunukan, P.Rote, Palu, Sangata, Sorong, Surabaya, Tahuna, Tarakan, Ternate, Timika, ToliToli, Tual) and selected ports in the assignment plan were 4 ports (Ambon, Makassar, Mataram, Tegal) while the ports not selected in the assignment plan were 3 ports (Balikpapan, Banyuwangi,
Semarang). As candidates for the starting point of the assignment, 4 (four) ports were produced as the starting point for assigning tankers. These ports consist of Ambon in charge of covering sectors 4, 5, 6 and 7, Makasar port which is in charge of sector 1 and to cover sector 3 while Tegal port is in charge of covering the patrol sector 2 .

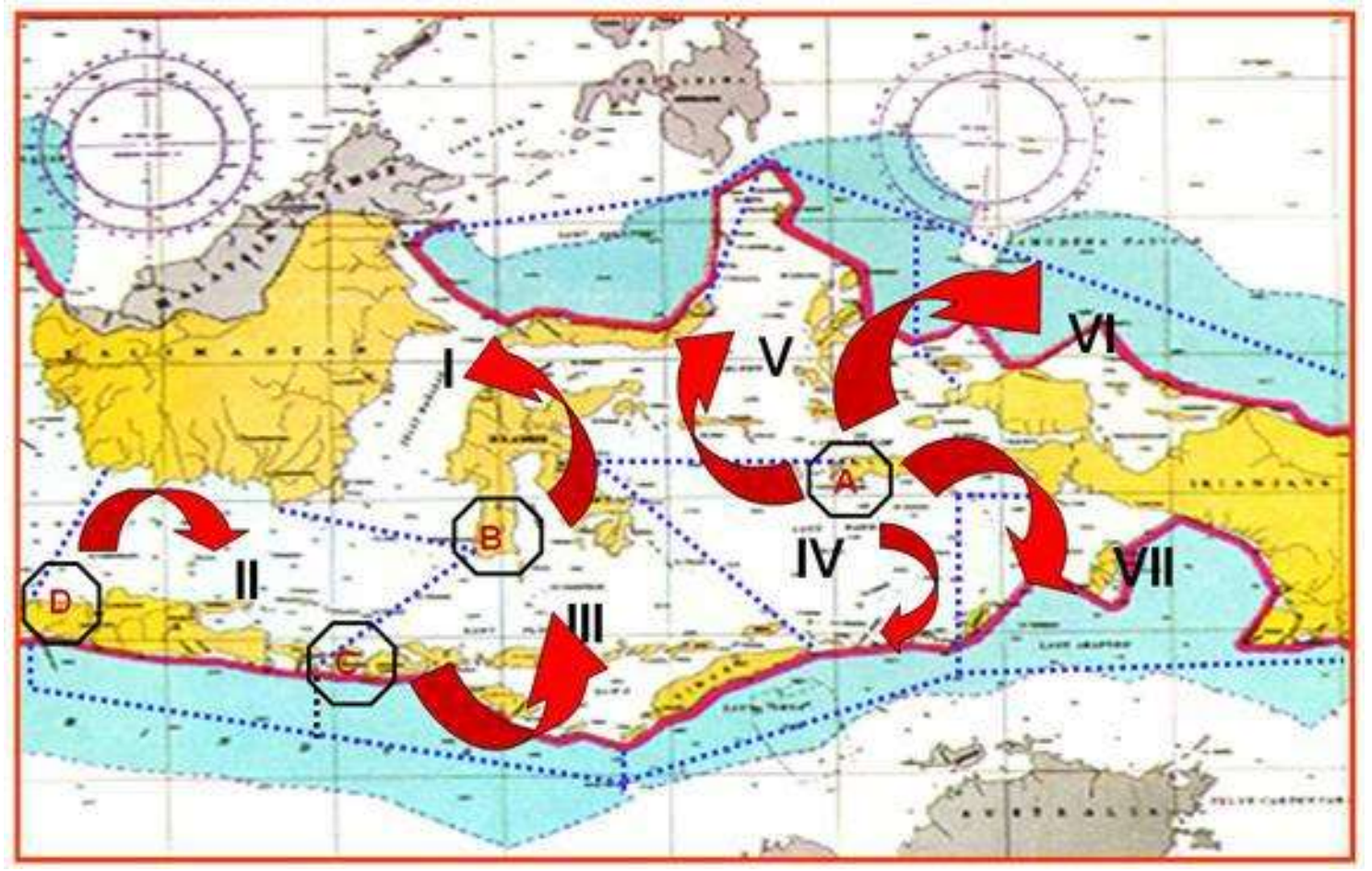

Fig. 8 Selected Port and Assignment Plan

\section{ACKNOWLEDGEMENTS.}

This research has been Supported by Indonesia Naval Technology College (STTAL).

\section{BIBLIOGRAPHY.}

A. Jayant, V.P.U.K. (2015) 'Application of Analytic Network Process (ANP) in Business Environment: A Comprehensive Literature Review', International Journal of Research in Mechanical Engineering \& Technology, vol. 5, no. 1, pp. 29-37.

Amir Azizi, R.m. (2014) 'Comparative Study of AHP and ANP on Multi-Automotive Suppliers with MultiCriteria', Proceedings of the International MultiConference of Engineers and Computer Scientists, Hong Kong, 1-6.
Ananiashvili, N. (2015) 'Solution of Problem of Set Covering by Means of Genetic Algorithm', Computer Science and Telecommunications, pp. 16-23.

Arica Dwi Susanto, A.O.S.S.I.G. (2017) 'Analysis of The Propulsion System Towards The Speed Reduction of Vessels Type PC-43', International Journal of Engineering Research and Application, vol. 7 , no. 4 , pp. 08-15.

Arica Dwi Susanto, A.A.O.S.S. (2018) 'The Optimization Of Multipurpose Building Development On Project Scheduling Using Precedence Diagram Method (PDM)', ASRO JOURNAL-STTAL, vol. 9, no. 1, pp. 1-7. 
Babak Daneshvar Rouyendegh, S.E. (2010) 'The DEA - FUZZY ANP Department Ranking Model Applied in Iran Amirkabir University', Acta Polytechnica Hungarica, vol. 7, no. 4, pp. 103-114.

Chih-Chieh Hung, W.-C.P.a.W.-C.L. (2012) 'Energy-Aware Set-Covering Approaches for Approximate Data Collection in Wireless Sensor Networks', IEEE TRANSACTIONS ON KNOWLEDGE AND DATA ENGINEERING, vol. 24, no. 11 , pp. 1993-2007.

Fabio De Felice, A.P. (2015) 'Multidimensional Balanced Efficiency Decision Model', Journal of Technology Management \& Innovation, vol. 10, no. 3, pp. 92-103.

I Nengah Putra, A.D.S.O.S.S. (2017) 'Comparative Analysis Results of Towing Tank and Numerical Calculations With Harvald Guldammer Method', International Journal of Applied Engineering Research, vol. 12, no. 21, pp. 10637-10645.

I Nengah Putra, A.D.S.H.L. (2017) 'Type of Ship Trim Analysis on Fuel Consumption with a Certain Load and Draft', International Journal of Applied Engineering Research, vol. 12, no. 21, pp. 1075610780.

Khademolqorani, S. (2016) 'Improved Association Rules Mining based on Analytic Network Process in Clinical Decision Making', (IJACSA) International Journal of Advanced Computer Science and Applications, vol. 7, no. 10, pp. 255-260.

Lami, F.A.a.I.M. (2012) 'Quality Function Deployment (QFD) and Analytic Network Process (ANP): an application to analyze a cohousing intervention', Journal of Applied Operational Research, vol. 4, no. 1, pp. 14-27.

Mattias Ohlsson, C.P.B.S. (2001) 'An Efficient Mean Field Approach to The Set Covering Problem',
European Journal of Operational Research, pp. 583-595.

Mohammadreza Shojaei, S.A.S.S.A. (2013) 'Using Analytical Network Process (Anp) Method To Prioritize Strategies Resulted From Swot Matrix Case Study: Neda Samak Ashena Company', INTERDISCIPLINARY JOURNAL OF CONTEMPORARY RESEARCH IN BUSINESS, vol. 4, no. 9, pp. 603-618.

Orestis A. Telelis, V.Z. (2005) 'Absolute o (logm) error in approximating random set covering:an average case analysis', Information Processing Letters 94, pp. 171-177.

Pi-Fang Hsu, M.-H.K. (2011) 'Applying the ANP Model for Selecting the Optimal Full-service Advertising Agency', International Journal of Operations Research, vol. 8, no. 4, pp. 48-58.

Răzvan Cătalin Dobrea, G.M.a.C.B. (2015) 'Food Sustainable Model Development: An ANP Approach to Prioritize Sustainable Factors in the Romanian Natural Soft Drinks Industry Context', Sustainability, pp. 10007-10020.

Saaty, T.L. (2004) 'Fundamentals of The Analytic Network Process-Dependence and Feedback in Decision-Making With a Single Network', JOURNAL OF SYSTEMS SCIENCE AND SYSTEMS ENGINEERING, vol. 13, no. 2, pp. 129-157.

Shawe-Taylor, M.M.a.J. (2002) 'The Set Covering Machine', Journal of Machine Learning Research, pp. 723-746.

Shunji Umetani, M.Y. (2007) 'Relaxation Heuristics For The Set Covering Problem', Journal of the Operations Research, vol. 50, no. 4, pp. 350-375.

Son, L.N. (2014) 'Consistency Test in ANP Method with Group Judgment Under Intuitionistic Fuzzy Environment', International Journal of Soft 
Computing and Engineering (IJSCE), vol. 4, no. 3,

pp. 68-71.

Suhas M. Gaikwad, R.R.J.P.M. (2015) 'Analytical Network Process (ANP) to Recommend an Ice Cream to a Diabetic Patient', International Journal of Computer Applications, vol. 121, no. 12, pp. 50-54. Takahashi, K.a.S.a.I. (2001) 'A Unified Model and Analysis For AHP and ANP', Journal of the Operations Research, vol. 44, no. 1, pp. 67-89.

Thangamani, G. (2012) 'Technology Selection for Product Innovation Using Analytic Network Process (ANP)-A Case Study', International Journal of Innovation, Management and Technology, vol. 3, no. 5, pp. 560-565.

Tian, Y. (2014) 'The Research on Energy-saving Technology of the Set Covering Base Station in Cellular Networks', The Open Automation and Control Systems Journal, pp. 1022-1028. 